WŁODZISŁAW ZEIDLER ${ }^{1}$

Studia Psychologica

UKSW

Hohenwestedt

16(1) 2016 s. $97-119$

\title{
POGLĄDY WILHELMA WUNDTA NA TEMAT \\ I WOJNY ŚWIATOWEJ
}

\begin{abstract}
Poniższy artykuł jest jedynie refleksją historyczną. Zatem pomimo możliwych przypadkowych podobieństw nie odnosi się do współczesności.
\end{abstract}

\section{STRESZCZENIE}

Wilhelm Wundt należał do tych uczonych oraz intelektualistów, którzy na temat I wojny światowej posiadali własne poglądy już wówczas, kiedy ta dopiero się zaczynała. W niniejszym artykule chcę odpowiedzieć na dwa pytania. Najpierw na to, które dotyczy osobliwości stanowiska Wundta, a następnie na to, które dotyczy wewnętrznej zgodności jego poglądów, to znaczy z jednej strony poglądów na temat wojny, a z drugiej - jego wcześniejszych, oryginalnych poglądów w zakresie filozofii i psychologii (np. etyka lub Völkerpsychologie). Stanowisko Wilhelma Wundta w odniesieniu do wojny w odróżnieniu od opracowań wcześniejszych - scharakteryzuję na podstawie trzech jego prac: Über den wahrhaften Krieg (1914), Die Nationen und ihre Philosophie (1915) oraz Zur Lage (1916, odpowiedź dla „Polnische Blätter”). Wykorzystanie tego trzeciego źródła, przez wiele dziesięcioleci pomijanego przez historyków psychologii (zarówno w Polsce, jak również w innych krajach) wyznacza specyfikę poniższego opracowania.

Słowa kluczowe: uczeni europejscy wobec I wojny światowej, „wspólnota w poddaństwie", interpretacja wojny przez F. Fischera, J. Leonhard o politycznych i kulturowych skutkach wojny, ,przewrót” Chr. Clarka, „wojna prawdziwa”, „narody oraz ich filozofia”, wizja przyszłej Europy

\section{WilhelM WUNDT'S OPINIONS ON The First World WAR}

\section{Abstract}

Wilhelm Wundt was one of those scientists and intellectualists, who had their own opinions on WWI even when it was just beginning. In the article the author wants to answer two questions. First, the answer the question concerning peculiarity of Wundt's stance. Second, answer the question of inner consistency of his opinions i.e. his outlooks

$1 \quad$ Adres do korespondencji: wlzeidler@gmail.com. 
on war and his earlier and original viewpoints on philosophy and psychology (i.e. ethics or Volkerpsychologie). Unlike in previous studies, Wilhelm Wundt's stance on war is characterized based on his three works: Über den wahrhaften Krieg (1914), Die Nationen und ihre Philosophie (1915) and Zur Lage (1916, the answer for „Polnische Blätter”). The inclusion of the third work, which for many decades was ignored by psychology historians (in Poland and in the other countries alike), is what makes this study distinct.

Keywords: European scientists to $1^{\text {st }}$ World War, "community in serfdom", interpretation of war by F. Fischer, Leonhard J. about political and cultural effects of war, "revolution" of Chr. Clark, "true war", "nations and their philosophy", vision of future Europe

\section{CEL I RAMY OPRACOWANIA}

Rozmaite uroczystości z okazji jubileuszu 100-lecia wybuchu I wojny światowej ożywiły zainteresowanie kilkoma nowymi aspektami tamtych wydarzeń. Opisom literackim i naukowym oraz analizom historycznym zaczęły towarzyszyć analizy działalności wybitnych postaci: owszem polityków, literatów, ale także uczonych. Poza konkretnymi wydarzeniami, w polu lub okopach, od dawna dostarczającymi tworzywa dla opisów literackich, zaczęto interesować się także poglądami oraz opiniami poszczególnych grup społecznych na temat przyczyn, przebiegu i sensu tej wojny. Zainteresowania te pojawiły się już w okresie jej trwania (np. Münsterberg, 1915). Skutki tej katastrofy, a w szczególności niezwykłe okrucieństwo, spowodowały, że owe zainteresowania, zrodzone z obywatelskiej refleksji i „zwykłego przerażenia”, zamieniły się w wielki ruch, nazwany pacyfizmem. Wiemy, że jednym z jego przedstawicieli był Albert Einstein, który w znanym liście (1972) skierowanym do Zygmunta Freuda domagał się ujawnienia motywów ludzkiej agresywności, która staje się przyczyną wojen. Jego zapytanie, skierowane wprost do Freuda, stanowiło także swoisty akt uznania dla społecznej rangi psychologii. Czy było to zaproszenie psychologii do dzieła budowania pokojowego współżycia obywateli krajów europejskich? Takiego współżycia, które dzięki zmianom cywilizacyjnym przestało być utopią i stało się krainą dostępną umysłom odważnym i refleksyjnym?

Wymowny przykład owego poczucia odpowiedzialności znajdziemy w liście Romaina Rollanda do Stefana Zweiga² z Genewy, z 10 października 1914 roku (2014, s. 51-52): „Powinniśmy się spotkać!... w jakimkolwiek neutralnym kraju, po to, aby swobodnie rozmawiać o tych wszystkich cierpieniach i niesprawiedliwościach, które wzajemnie, sobie zadajemy!”. Dla obydwu, zaraz na początku owej Grand Guerre, było rzeczą oczywistą, że pod ogólnie znaną, „oficjalną” polityczno-militarną fasadą ukrywa się jeszcze inna warstwa, głębsza, jednostkowa, ludzka i „humanistyczna” - wolna od niechęci i brutalnej wrogości. Nie było w tym nic dziwnego, że najpierw pojawiła się ona w przeżyciach i poglądach

2 Sens tej wypowiedzi stanie się bardziej wyrazisty, jeżeli uświadomimy sobie, że Austria i Francja znajdowały się wówczas w dwóch wrogich obozach zaangażowanych w tej wojnie. 
wielkich uczonych oraz intelektualistów. Czy w tamtym czasie, na to przyszłe pytanie Einsteina - dotyczące psychologicznych przyczyn wojen oraz agresywności - nie znano jeszcze żadnej odpowiedzi? Czy psychologowie na temat wojny nie mieli jeszcze nic do powiedzenia?

\section{Polaryzacja POglądów EUROPEJSKich UCZONYCh NA TEMAT I WOJNY ŚWIATOWEJ}

Wkrótce po wybuchu I wojny światowej nastąpiła polaryzacja postaw uczonych, intelektualistów oraz artystów w odniesieniu do kontaktów i stosunków międzynarodowych (np. Hoeres, 2004; Leonhard, 2014, s. 235 i nn.). Zamiast syntonii wyrażonej przez Zweiga i Rollanda, postawy tej grupy zaczął charakteryzować wysoki poziom agresywności. Podobne obserwacje - po drugiej stronie Oceanu - odnotował już 15 sierpnia 1914 roku w swoistym dzienniku Hugo Münsterberg (1915, s. 63-72). Stało się teraz tak, że w wypowiedziach uczonych oraz intelektualistów miejsce dotychczasowego internacjonalizmu zajął swoisty nacjonalizm. Swoisty, ponieważ pochodny nie w stosunku do narodowości, ale wynikający z „przynależności imperialnej”. On też stał się podstawą dla agresywności zarówno w stosunkach międzynarodowych, jak i osobowych. Były to agresje, które zamiast na polach bitew miały miejsce w zakresie kontaktów handlowych oraz dotychczasowej współpracy naukowej i kulturalnej. Było to tym bardziej dziwne, jeżeli zważymy, że wybuch tej wojny nie miał jasnych i zadowalających uzasadnień (Leonhard, 2014, s. 235 i nn.), co zmuszało do „dorabiania teorii” do zaistniałych faktów. Owo zapotrzebowanie mieli zaspokoić dziennikarze, publicyści, artyści oraz uczeni. Peter Hoeres (2004) omówił szczegółowo te właśnie aspekty w odniesieniu do Niemiec oraz Wielkiej Brytanii. „Dorabianie teorii” było poszukiwaniem uzasadnień lub pseudouzasadnień dla działań agresywnych, które już się wydarzyły. Był to jeden $\mathrm{z}$ argumentów, które ujawniały i akcentowały irracjonalność, ba, wręcz absurdalność agresji, co zauważyli pisarze (np. E.M. Remarque).

Leonhard i Hoeres przypominają, że Ernst Troeltsch ${ }^{3}$ dostrzegał przyczyny wybuchu I wojny światowej w zmianach - społecznych, politycznych oraz kulturowych - europejskich struktur narodowych lub państwowych. Zwycięstwo Niemiec nad Francją i utworzenie Cesarstwa w roku 1871 miały zamknąć proces formowania się niemieckiej świadomości narodowej. Było to oczekiwanie absurdalne, albowiem ówczesne europejskie „cesarstwa” były państwami wielonarodowymi! Powstawały przecież dzięki agresji i na zasadzie przymusu. To zaś znaczyło, że ich struktura państwowa nie była identyczna ze strukturą narodową! Troeltsch (por. Leonhard, 2014, s. 237) traktował opozycję w stosunku do absolutyzmu cesarstwa rosyjskiego oraz zakresy wolności osobistej jako

3 Ernst Troeltsch (1865-1923) - niemiecki filozof oraz działacz partii liberalnej. 
elementy stanowiące podstawę „narodowej wspólnoty”, która w rzeczywistości była imperialną strukturą państwową. Jednakże albo świadomie, albo tylko „Z niedopatrzenia” Troeltsch nie dostrzegał różnicy między „wspólnotą narodową" z jednej a „wspólnotą w poddaństwie” z drugiej strony. Sądzić należy, że wśród intelektualistów istniało zróżnicowanie na zorientowanych na wartości patriotyczne oraz na preferujących wartości humanistyczne.

Tabela 1

Fragmenty kalendarium I wojny światowej

$>01.08$. 1914. Po zamachu w Sarajewie, po wypowiedzeniu wojny Serbii i mobilizacji w Rosji, Niemcy wypowiedziały wojnę Rosji.

$>04.08$. 1914. Po wkroczeniu Niemiec do Belgii Wielka Brytania wypowiedziała wojnę Niemcom.

>Wkrótce po wybuchu wojny przestaje funkcjonować, założone w roku 1899, Internationale Assoziation der Akademien, którego inicjatorem i organizatorem były Niemcy.

>07.09. 1914. 31 profesorów niemieckich uczelni wyższych (wśród nich Wilhelm Wundt) zrzeka się, otrzymanych uprzednio, brytyjskich odznaczeń akademickich.

>10.09. 1914. Wundt wygłasza w Lipsku przemówienie Über den wahrhaften Krieg.

$>14.09$. 1914. Wundt należy do grupy niemieckich intelektualistów, którzy podpisali deklarację wzywającą do udziału w wojnie.

>18.09. 1914. Londyński „Times” publikuje deklarację 53 brytyjskich intelektualistów, popierających wojnę z Niemcami.

$>04.10$. 1914. W gazetach niemieckich ukazało się podobne poparcie dla wojny, podpisane przez 93 niemieckich intelektualistów. Wundt był jednym z nich. Ale jednocześnie - z inicjatywy Alberta Einsteina ukazała się deklaracja przeciwników wojny, podpisana tylko przez sześciu uczonych.

$>$ Jesień 1914. Decyzją moskiewskiego ministerstwa oświaty, Wilhelm Wundt oraz Wilhelm Windelband zostają pozbawieni honorowego członkostwa, które w roku 1888 przyznało im Towarzystwo Psychologiczne w Moskwie.

Źródło: Zeidler (2008), opracowano na podstawie P. Hoeres (2004).

Leonhard (2014, s. 240) przypomniał odezwy z 4 października 1914 roku (podpisaną przez 93 wybitnych niemieckich pisarzy i uczonych) oraz tę z 16 października 1914 roku (podpisaną przez 4000 niemieckich nauczycieli akademickich), tłumaczące popełnione okrucieństwa (Belgia, Leuven), aby wyjaśnić 
sprzeczności między niemiecką kulturą oraz niemieckim militaryzmem, który teraz stał się narzędziem niszczącym kulturę innych narodów.

Wiemy, że ta nieoczekiwana konfrontacja stała się przyczyną konfliktu, który przeciwstawił sobie braci Tomasza i Henryka Mannów. W rzeczywistości był to wręcz splot konfliktów w społeczeństwie niemieckim, który nagle zaczął rozdzielać całe społeczności i rozmieszczać je po wrogich sobie stronach tej samej barykady! Naprzeciw tradycji stawała rewolucja, demokracja próbowała wyprzeć orientację monarchistyczną, a cywilizacja stawała się przeciwnikiem kultury. Ten szeroki strumień intelektualnych niepokojów oraz sprzeczności znajdował wyraz zarówno w działaniach całych grup (odezwy!), jak i poszczególnych jednostek (wystąpienia, publikacje). Czy były to wyłącznie aktywności wtórne, towarzyszące działaniom wojennym lub przez nie wywoływane, czy może takie, przez które działania wojenne były wręcz motywowane lub wspomagane?

Krytyczny stosunek do wojny wyrażają prace wspomnianego już Hugona Münsterberga (1863-1916) ${ }^{4}$ - Gdańszczanina z urodzenia, ucznia Wilhelma Wundta i profesora Uniwersytetu Harwarda. Münsterberg opublikował swoje poglądy drukiem po drugiej stronie Oceanu, w Nowym Yorku, równolegle do wydarzeń wojennych. Już we wrześniu 1914 roku ukazała się pierwsza praca: The War and America, a wkrótce potem, w kwietniu 1915 roku, druga: The Peace and America. Także w roku 1915 w Lipsku ukazało się tłumaczenie na niemiecki obydwu prac w jednym tomie pt. Amerika und der Weltkrieg - ein amerikanisches Kriegstagebuch. Przedmowę do tej książki Münsterberg sygnował 1 lipca 1915 roku w Boston-Cambridge. Większość Amerykanów miała $\mathrm{w}$ tym czasie nastawienie anglofilskie, które pozostaje $\mathrm{w}$ symbiozie $\mathrm{z}$ rodzimym pragmatyzmem. Tymczasem Münsterberg, chociaż jest teraz obywatelem Nowego Świata, troszczy się nadal o los swojej starej Ojczyzny, która pozostała po drugiej stronie Oceanu. Dlatego stara się być pośrednikiem. Podkreśla zatem, że w jego książce każde zdanie uwzględnia istniejące w USA uprzedzenia i wiedzę Amerykanów, a tam, gdzie trzeba - także ich brak wiedzy (Münsterberg, 1912, 1915, s. 11). Już w sierpniu 1914 roku (!) zdaje sobie sprawę z tego, że wojna ta będzie tak wielka i tak okrutna, jakiej świat jeszcze nie przeżył (1915, s. 13). Jako lekarz i psycholog dostrzega traumatyzujący wpływ wydarzeń wojennych. Emocjonalnie jest im przeciwny, zatem poszukuje rozwiązania w płaszczyźnie intelektualnej. Analizuje aktywne, a po części wzajemnie sprzeczne struktury społeczne i polityczne, rządzące życiem państw stanowiących strony konfliktu. Wrogie, zwalczające się z rosnącą zaciekłością na coraz to nowych frontach wojny. Jako dociekliwy psycholog ${ }^{5}$ zdaje sobie sprawę z tego, że „źródło” owych walk i trwałych konfliktów nie tkwi w jednostkach, ale w owych strukturach,

\footnotetext{
Więcej: Lück (1997) lub Zeidler (2011, s. 43).

5 Wiadomo, że Hugo Münsterberg doktoryzował się pod kierunkiem Wundta w zakresie Völkerpsychologie.
} 
które w perspektywie minionych stu lat, według przenośni Christophera Clarka (2013), należałoby nazwać lunatycznymi. Szykanowany z powodu swoich pacyfistycznych przekonań, Hugo Münsterberg zmarł nagle w roku 1916.

\section{WOJNA I POSZUKIWANIE TOŻSAMOŚCI PSYCHOLOGII}

Na początku XX wieku psychologia miała już zadatki swojej tożsamości, chociaż jej egzystencję redukowano do społeczności akademickiej i definiowano zgodnie $\mathrm{z}$ kanonami nauki pojmowanej pozytywistycznie. Inne konwencje oraz sposoby uprawiania psychologii (np. psychoanaliza, psychotechnika, charakterologia) nie cieszyły się jeszcze społecznym uznaniem. Dla rozwoju psychologii jako nauki szczególnie ważne znaczenie miały opinie środowiska uniwersyteckiego, ale także tzw. instytucjonalizacja psychologii (por. np. Schönpflug, 2000; Staeuble, 1985). Znalazła ona już na początku XX wieku wyraz w postaci tworzenia uniwersyteckich katedr psychologii (por. np. Ash, 1980), zastosowania psychologii w praktyce (np. Münsterberg, 1916), tworzenia stowarzyszeń naukowych oraz czasopism psychologicznych (por. Schönpflug, 2000, s. 308). Społeczne zainteresowanie - jak to widzieliśmy w przypadku Münsterberga - stanowiło także rodzaj presji społecznej. Oczekiwano, że psychologowie przyłączą się do ogólnego entuzjazmu i w patriotycznym uniesieniu staną się zwolennikami wojny. Ci, którzy nie interesowali się nią, należeli do wyjątków. Jednym z nich był Carl Stumpf, którego - w adresie z okazji 80. urodzin - podziwiał Wolfgang Köhler (1928) z tej racji, że pomimo trwania wojny nadal prowadził (był w stanie nadal prowadzić?) swoje pionierskie badania w zakresie psychologii wrażeń słuchowych!

Tymczasem niezależnie od sympatii i lęków poszczególnych psychologów, psychologia akademicka, pozostając w zależności od ośrodków władzy, nie mogła wybierać obiektów swoich zainteresowań i badań ani według własnego upodobania, ani według życzeń „publiczności” zgromadzonej i uwięzionej we „wspólnocie poddaństwa”. Kiedy Carl Stumpf prowadził pokojowe badania naukowe, jego asystenci albo walczyli na froncie (Kurt Lewin), albo prowadzili badania na rzecz armii (np. Max Wertheimer). Geuter (1985) pokazał bardzo wyraziście cały proces „przygotowania” psychologii do udziału w prowadzeniu działań militarnych.

W tym kontekście zainteresowanie budzi to, jakie nastawienie w stosunku do I wojny światowej miał twórca psychologii naukowej. Oczywiście potraktowanie Wundta przez autorów z dawnej NRD (Meischner, Eschler, 1979) jako przedstawiciela niemieckiego militaryzmu raziło powierzchownością ${ }^{6}$.

$6 \quad$ Z drugiej strony, nasz sąd byłby także powierzchowny lub wręcz błędny, gdybyśmy za punkt wyjścia interpretacji lub podstawę oceny przyjęli wyłącznie panujące wówczas w NRD dyrektywy ideologiczne. Należy zatem zauważyć i podkreślić, że tego rodzaju oceny - owszem, 
Ustosunkowanie Wundta do wojny było bardzo złożone. Zawierało bowiem zarówno wątki patriotyczne lub emocjonalne, jak też miało uzasadnienie racjonalne oraz intelektualne, wynikające $\mathrm{z}$ jego poglądów filozoficznych, ale niekoniecznie psychologicznych. Poglądy te powstały przed wybuchem wojny i były od niej całkowicie niezależne. To z kolei znaczyło, że już w chwili wybuchu wojny poglądy Wundta na jej temat, choć wymagały artykulacji, w zasadzie były już „gotowe". To właśnie one będą tutaj stanowiły przedmiot naszego zainteresowania. Jednak należy dodać, że ani w publikacjach, ani w prywatnej korespondencji (np. z Kraepelinem; Steinberger, 2002) Wundt nie wyrażał swoich prywatnych poglądów na temat wojny, chociaż jako ojciec syna (Max Wundt, 1879-1963) walczącego w okopach pod Verdun mógł mieć taką potrzebę.

Jeden $\mathrm{z}$ bardziej dociekliwych biografów Wilhelma Wundta (Lamberti, 1995, s. 158) jest zdania, że jego stosunek do I wojny światowej był jakby dwufazowy. Fazę pierwszą cechował patriotyczny idealizm. Druga faza - już podczas trwania wojny - powstała i rozwijała się jako wynik korespondencji z synem Maxem. Wojna ukazywana $z$ bliska była pełna niebezpieczeństw, okrucieństw i bólu. Wundt liczył sobie 82 lata! Jego wiedza, także filozoficzna, nie dostarczała teraz zadowalającej ochrony przed naporem doznań zaskakujących brutalnością i tragizmem. Jego stosunek do wojny, zamiast patriotycznego idealizmu, zaczął teraz charakteryzować realizm, zdeterminowany przez doznania codziennej rzeczywistości, zrozumienie niesprawiedliwości oraz bólu innych.

W celu lepszego zrozumienia dalszych uwag na temat stosunku Wilhelma Wundta do I wojny światowej należy w tym miejscu zwrócić uwagę na to, że w związku z istnieniem dymensji czasowej i spowodowanym przez nią zachodzeniem na siebie różnych poglądów, przez ową rzeczywistość wręcz wymuszanych, konieczne są pewne dystynkcje. Ta pierwsza nawiązuje do znanego powiedzenia, którego autorem ma być Golo Mann: każde pokolenie pisze historię dla siebie i od nowa. Obraz i poczynania Wundta na tle historii jego czasu mogą być inne niż na tle naszego czasu, ale także czasów pośrednich. Z punktu widzenia wspomnianych wyżej Meischnera i Eschlera (1979), ze względu na obowiązującą ideologię (NRD), można było postrzeganie postępowania Wundta „dopasować” do aktualnych dyrektyw ideologicznych lub politycznych i nazywać go „militarystą", nie zastanawiając się wcale nad tym, że militarysta jest w tym przypadku

„wówczas i tam” - opierały się w różnych krajach i w różnych okresach na przesłankach czerpanych z panujących w danym momencie doktryn ideologicznych lub politycznych. $\mathrm{Na}$ tle „przełomu Fischera“ formułowano także inne oceny postawy Wundta niż te, które stały się oczywistością w kontekście „przełomu Clarka”. Ramy tego opracowania nie pozwalają jednak na dokładniejszą dokumentację tego stanowiska.

7 Terminem „poglądy“ posługuję się tutaj wówczas, kiedy mam na myśli pewien system wiedzy dotyczący danego przedmiotu oraz odpowiednią, specyficzną strukturę wartościującą. Zakładam przy tym, że ani owa „wiedza”, ani system wartości nie zostały przyswojone lub narzucone przez otoczenie, tylko stanowią dorobek danej osoby, jej intelektualną własność. 
etykietą, a nie nazwą. Jednostronne spojrzenie na historię można odnaleźć także w napisanej przez Franza Fischera (1908-1999) i szeroko dyskutowanej pracy Grif nach der Weltmacht (1961), w której przyjął (obecną już w traktacie wersalskim) tezę o jednostronnej odpowiedzialności Cesarstwa Niemieckiego za wybuch i losy I wojny światowej ${ }^{8}$. Wpływ tego poglądu, w zasadzie zgodnego z postanowieniami traktatu wersalskiego, można rozpoznać w szeregu sformułowań, które występują w - skądinąd pionierskich i wartościowych - opracowaniach Scheerera (1989) oraz Schubeius (1990), które zainicjowały dalszy ciąg refleksji nad wpływem I wojny światowej na zainteresowania psychologów jej problemami. Tutaj pomijam je w całości, ponieważ dotyczą odmiennej problematyki, przedmiotem naszego zainteresowania są bowiem poglądy jednego psychologa: Wilhelma Wundta. Dodać należy, że w międzyczasie zmieniły się także poglądy historyków na temat przyczyn wojny, a także odpowiedzialności za jej wybuch oraz przebieg. Można powiedzieć, że ów „przewrót Fischera” zastąpił teraz „przewrót Christophera Clarka", ukazał bowiem złożoność problematyki związanej z odpowiedzialnościąz a wojnę orazza jej przebieg wsposób dociekliwy, nowoczesny i przekonujący (Clark, 2012, 2014). W podobnie zróżnicowany i wielostronny sposób rozpatruje historię i problemy wojny Jörn Leonhard (2014), koncentrujący się na innych aspektach tej problematyki. Owszem, te militarne były ważne, ale obok politycznych Leonhard dostrzega znaczenie tych, które były związane z przemianami kulturowymi i procesami tworzenia się narodów lub odzyskiwania przez nie wolności i poczucia tożsamości. Zarówno Clark, jak i Leonhard w swoich opisach i analizach I wojny światowej wychodzą poza dotychczasowe schematy militarno-polityczne i pokazują inne oblicza wojny - te humanistyczne, patriotyczne i kulturowe. Przy takim podejściu także problem odpowiedzialności ukazuje się nam w nowym świetle, a aktorzy wojennych wydarzeń - jak chce Clark (2012) - sami siebie redukują do „lunatyków”. Taka zmiana perspektywy najpierw zaskakuje, ale już niebawem staje się zrozumiała. Jako, wprawdzie ukrytą, ale wieloraką przyczynę tej wojny rozpoznajemy zatarcie różnic i podobieństw między tym, co oznaczamy terminami „naród” oraz „państwo”, i redukowaniem ich do usłużnej formuły „imperium”. W tej wojnie stały naprzeciw siebie, w obronie własnych, egoistycznych interesów, w zasadzie tylko imperia: Rosja, Niemcy, Francja, Wielka Brytania, ale także Imperium Osmanów. Pomimo to obiegowymi argumentami propagandy każdego z tych imperiów były „patriotyzm” i „ojczyzna”. Ale czy imperium mogło być „ojczyzną”?

8 „...trägt die deutsche Reichsführung einen erheblichen Teil der historischen Verantwortung für den Ausbruch des allgemeinen Krieges“ (Fischer, 1961, s. 97). „Władze Cesarstwa Niemieckiego są w znacznej części historycznie odpowiedzialne za wybuch wojny powszechnej" (tłum. W.Z). 


\section{MATERIAE WYBRANY DO INTERPRETACJI}

Materiał stanowiący podstawę niniejszego opracowania pochodzi z terenu istniejącego do końca I wojny - Cesarstwa Niemieckiego, a dokładniej: z terenu Saksonii, która była w tym czasie częścią tego Cesarstwa, ale pozostawała nadal odrębną monarchią, istniejącą w ramach tegoż imperium. Oznaczało to swoistą autonomię i specyficzne podstawy prawne funkcjonowania Kraju oraz jego uniwersytetów. Dla poddanych cesarza w sytuacji tej tkwił szereg wyzwań i trudności związanych z określeniem własnej tożsamości, owszem, także tej narodowej. Należy dodać, że już w trakcie wojny wybitni intelektualiści cesarstwa byli skłonni traktować ową wojenną zawieruchę jako kryzys kultury. Bardzo dobitnie wyraził to niemiecki socjolog Georg Simmel: „Skoro są to symptomy chorej kultury, to w takim razie czy w o j n a oznacza wybuch k r y z y s u, który może być początkiem rekonwalescencji?” (Simmel, 2007, s. 75).

Wiadomo, że w literaturze oraz archiwach z tamtego czasu można znaleźć wiele dokumentów dotyczących wojny. Takie, które przed rozpoczęciem wojny przestrzegały, i takie, które do niej zachęcały. Takie, które powstały przed wojną, i takie, które koncentrowały się na jej przebiegu albo skutkach. Istnieją świadectwa tych, którzy wojnę planowali, i tych, którzy stali się tej wojny ofiarami. W literaturze społecznej oraz naukowej znajdziemy wypowiedzi ludzi, którzy oglądali wojnę $\mathrm{z}$ bezpiecznego dystansu, ale $\mathrm{z}$ tragicznym zainteresowaniem. Wundt należał do tej ostatniej grupy. Wojnę przeżywał jako patriota, jako uczony i filozof, ale też jako ojciec syna ${ }^{9}$ walczącego w okopach pod Verdun.

$\mathrm{W}$ ramach tego opracowania wykorzystam trzy źródła, które dokumentują jedynie te „oficjalne” poglądy Wundta na temat wojny. Pierwszym z nich, chronologicznie, jest jego przemówienie na temat rozpoczynającej się wojny, wygłoszone w Lipsku 10 września 1914 roku: Über den wahrhaften Krieg (Wundt, 1914). Drugim jest broszura Die Nationen und ihre Philosophie (Wundt, 1915). Trzecim wreszcie odpowiedź na zapytanie „polskiego” czasopisma o to, jak będzie wyglądała sytuacja Polski po zakończeniu wojny (Wundt, 1916). Dwa pierwsze źródła - szeroko znane i często dyskutowane - zawierają odpowiedzi Wundta na pytania, które stawiała mu otaczająca go rzeczywistość, podporządkowana imperialnej polityce cesarstwa, a także jego patriotyzm i świadomość historyczna. Źródło trzecie - prawie że nieznane, albo wręcz ignorowane i zapomniane - to odpowiedź na pytanie $\mathrm{z}$ wojną wprawdzie związane, ale ewidentnie wyprzedzające bieg wydarzeń i ujawniające stosunek Wundta do jednego z sąsiadów, który w tamtym czasie był tylko narodem, gdyż nie miał tożsamości państwowej.

9 Max Wundt (1879-1963) - syn Wilhelma Wundta, był profesorem filozofii i autorem szeregu prac - także z pogranicza filozofii - które cechował nacjonalizm i antysemityzm. Ich tematyka dotyczyła także kwestii z zakresu Völkerpsychologie (por. np. Eilers, 1928), co było m.in. powodem tego, że niektórzy „przypisywali” cały dorobek i poglądy Maxa Wundta także jego ojcu Wilhelmowi. 
Właśnie w tej odpowiedzi Wundta znalazły praktyczne zastosowanie poglądy wyrażone przez niego w dwóch pierwszych źródłach, a także w innych, wcześniejszych pracach teoretycznych, zaliczanych do Völkerpsychologie. Ta krótka wypowiedź, przez jego biografów, także polskich psychologów, uparcie ignorowana, jest dowodem konsekwencji Wundta w rozumowaniu oraz spójności jego poglądów.

Jest rzeczą zrozumiałą, że wymienione źródła dostarczają materiału do i n t e r p r e t a c j i. Jak już powiedziałem, w stosunku do interpretacji wcześniejszych, biorę tutaj pod uwagę - w odróżnieniu od Scheerera (1989) oraz Schubeius (1990) - także źródło dodatkowe: odpowiedź Wundta na zapytanie polskiego czasopisma jeszcze w trakcie trwania wojny. Jest rzeczą oczywistą, że odpowiedź Wundta nie była zgodna z politycznymi deklaracjami niemieckiego cesarstwa, a to przekonuje o jego otwartości. W swojej istocie antycypowała deklarację, plan pokojowy prezydenta Wilsona z 8 stycznia 1918 roku. Dlaczego do tej pory inni autorzy jej nie zauważyli i nie wykorzystali? Owszem, w Polsce ${ }^{10}$. Egzemplarze tego pisma znajdują się przecież nie tylko w trudno dostępnym oddziale Biblioteki UAM w Poznaniu.

\section{TRZY WY POWIEDZI WILHELMA WUNDTA NA TEMAT I WOJNY ŚWIATOWEJ}

Podstawowe elementy ustosunkowania Wilhelma Wundta do wojny znalazły wyraz w jego przemówieniu z 10 września 1914 roku w Alberthalle w Lipsku. Przemówienie miało tytuł Über den wahrhaften Krieg i zostało opublikowane w osobnej broszurze (40 stron). Uchodzi ono za dowód zaangażowania Wundta w problematykę wojny i artykulację jego stosunku do niej (por. Hoeres, 2004, s. 276). Inni autorzy sądzą, że Wundt jest w tym przemówieniu woluntarystycznym idealistą. Meischner i Eschler (1979, s. 97) zinterpretowali je, zgodnie z klasową ideologią NRD, jako wezwanie do wojny w interesie niemieckiego imperializmu. W ich ocenie Wundt był militarystą oraz nacjonalistą. Lamberti (1995) - jeden z bardziej cenionych biografów Wundta - stanowiska ich nie podzielał. Dobre tło dla tego przemówienia może stanowić fakt, że w roku 1909 Senat Uniwersytetu w Lipsku prosił Wundta o wygłoszenie uroczystej mowy w ramach uroczystości jubileuszu 500-lecia Alma Mater Lipsienis. Przemówienie

10 To trzecie źródło odnalazłem jesienią 2007 roku podczas kwerendy w Bibliotece UAM w Poznaniu. Był to list Wilhelma Wundta zatytułowany Zur Lage, opublikowany w czasopiśmie „Polnische Blätter”, w Charlottenburgu w roku 1916 (t. 5, s. 99-101). Stanowił on odpowiedź na zapytanie redaktora tego pisma, Wilhelma Feldmana (1868-1919), o poglądy Wundta na temat przyszłości „Polski” po zakończeniu wojny. Tenże Feldman był w okresie międzywojennym wysoko cenionym historykiem literatury polskiej, a jako redaktor „Polnische Blätter” był członkiem Legionów Piłsudskiego i prowadził na terenie Cesarstwa Niemieckiego agitację na rzecz Niepodległości Polski. O treści tego listu informowałem też już wcześniej (Zeidler, 2008). Inspirowała ona powstanie niniejszego artykułu. 
spotkało się z wielkim uznaniem i zostało gorąco przyjęte przez wszystkich uczestników ceremonii. Wundt był w Lipsku szeroko znany i popularny, dlatego też był najwłaściwszym mówcą w Alberthalle na wiecu, który miał zachęcać do udziału w wojnie.

W konstrukcji jego przemówienia można wyróżnić trzy części. W części pierwszej autor stara się odpowiedzieć na pytanie, o jakiej wojnie chce mówić (wahrhafte Krieg). W części drugiej opisuje dokładniej przeciwników oraz ich zamiary. A w części trzeciej skrótowo, jednak bardzo dobitnie przedstawia wizję przyszłości Europy po zakończeniu Grand Guerre. Tłem dla uwag wyjściowych było przypomnienie sławnej bitwy narodów pod Lipskiem, której pomnik został odsłonięty w setną rocznicę bitwy, 18 października 1913 roku. Według eksplikacji Wundta, w tamtej bitwie narody Europy broniły się przed zniewoleniem przez pewnego despotę. Była ona zatem wojną słuszną. Taką jest bowiem tylko ta wojna, którą dany naród (dodajmy, że Wundt ma na myśli nie państwo, ale właśnie naród: Volk) prowadzi przeciwko wrogowi usiłującemu pozbawić go wolności i samodzielności (Wundt, 1914, s. 3). Obie one są bowiem potrzebne, aby każdy naród mógł w sposób aktywny i twórczy uczestniczyć w działalności wspólnoty kulturowej, której jest częścią (Wundt, 1914, s. 4). Każdy naród ma prawo, ale i obowiązek obrony swojej egzystencji (Wundt, 1914, s. 5). Jest rzeczą interesującą i godną podkreślenia, że w tym fragmencie przemowy Wundt nie posługiwał się pojęciem „państwa”, a tym bardziej „cesarstwa”. Tym samym należy zauważyć, że jego wypowiedzi nie można redukować do ówczesnych obiegowych kategorii politycznych. Znajdowały one natomiast oparcie i uzasadnienie w jego Völkerpsychologie, którą postulował i nad którą pracował od roku 1863.

W drugiej części swojego wystąpienia Wundt skoncentrował się na identyfikacji oraz charakterystyce głównych przeciwników: Anglii i Rosji. Był on przy tym świadom, że o udziale Wielkiej Brytanii w wojnie nie zadecydował naród, ale sfery nią rządzące (Wundt, 1914, s. 14). Motywacja wynikała z gospodarczej rywalizacji (utrzymanie kolonii, przewaga na morzu), a wspomagały ją zasada egoistycznej korzyści oraz etyczny utylitaryzm (Wundt, 1914, s. 21), od dawna obecne w angielskiej filozofii. Poglądów Wundta na temat udziału Rosji w wojnie nie będę analizował szczegółowo, ograniczę się do wskazania tylko jednego wątku. Wundt był zdania, że od czasów Piotra Wielkiego Rosja skrzętnie przyswajała sobie wszelkie zdobycze techniki, ale jednocześnie utrudniała wszystkim zniewolonym narodom dostęp do kultury europejskiej, czyniąc zarazem wszystko, aby pozbawić je tej kultury, którą same stworzyły. Zarzut ten Wundt egzemplifikuje przykładem Polski: „We włączonych do jej królestwa, 
zniewolonych Polskich prowincjach, nawet w okresie pokoju, panuje ciągły stan oblężenia"11 (Wundt, 1916, s. 36, tł. W.Z.).

W trzeciej części broszury, na kilku ostatnich stronach Wundt zastanawia się nad przyszłością Europy po zakończeniu wojny. Opowiada się po stronie tych, których nadzieją jest trwały pokój, jego podstawę będzie stanowiła przyszła Federacja Europy Środkowej, której zarysy wyłonią się i skrystalizują już $\mathrm{w}$ trakcie dalszych działań wojennych. Będzie to federacja podobna do już istniejącej i funkcjonującej jako Unia w Ameryce Północnej. Takie były przewidywania i pragnienia Wilhelma Wundta zaraz na początku Grand Guerre. Były one niezwykle odważne i niecierpliwe. Wychodziły poza obowiązujące wówczas układy i konwencje polityczne. Wyprzedzały też swój czas, niektóre niemal o cały wiek! Dodać zatem należy, że nie były one tylko produktem „patriotycznych marzeń", ale wynikiem rozumowania, które stanowiło konkluzję opartą na określonych przesłankach filozoficznych oraz dociekaniach, z których powstała Völkerpsychologie. Jak już stwierdziliśmy, Wundt był przeciwnikiem egoizmu i utylitaryzmu. Tak, był idealistą i był przekonany, że ludzie są istotami rozumnymi.

Die Nationen und Ihre Philosophie (Narody oraz ich filozofia; Wundt, 1915). Już na wstępie Autor podkreśla, że związek rozważań zawartych w tym opracowaniu z toczącą się wojną jest tylko częściowy. W rzeczywistości prezentowane tutaj myśli były przedmiotem jego zainteresowania oraz analiz już znacznie wcześniej. Jest to ważne stwierdzenie, które przez wielu autorów było ignorowane. Punktem wyjścia była refleksja nad tym, co zwykle nazywa się światopoglądem, czyli sposobem percypowania i pojmowania świata, przy założeniu, że $\mathrm{i}$ świat, i jego percepcja są zmienne historycznie. Wundt ma w tym miejscu na myśli zmianę dotychczasowych poglądów na świat, która zachodziła wprawdzie stopniowo, ale konsekwentnie, poczynając od ogłoszenia dzieła Mikołaja Kopernika (1473-1543) De revolutionibus orbium coelestium. Istota tych przemian polegała na budowaniu elementów tworzących światopogląd $\mathrm{z}$ coraz to nowych rezultatów przyrodniczego poznania naukowego. Ze względu na język, którym posługiwali się w swoich dociekaniach ówcześni uczeni i filozofowie, wszystkie te nowe osiągnięcia mogły najpierw upowszechniać się w kraju, którego nowoczesny język był najbliższy łacinie. W swoich rozważaniach szczegółowych (56 stron) Wundt ogranicza się do filozofii i opisuje jej rozwój i osiągnięcia w czterech krajach: Włoszech, Francji, Anglii oraz Niemczech - w tej właśnie kolejności, ponieważ w takim porządku filozofia osiągała $\mathrm{w}$ każdym $\mathrm{z}$ wymienionych krajów szczytowe punkty swojego rozkwitu, które okazywały się ważne

11 Jest rzeczą zrozumiałą, że Wundt w swoim liście do „Polnische Blätter” napisał to zdanie w języku niemieckim: Es hat die seinem Reiche einverleibte Polnische Provinzen derart geknechtet, dass der Zustand Russisch-Polens in Friedenszeiten ein fortdauernder Belagerungszustand ist (Wundt, 1916, s. 36). 
i znaczące dla ewolucji całej filozofii europejskiej. Specyfika rozwoju oraz jego „produkty” były determinowane, mniej lub bardziej wyraziście, przez rozmaite wydarzenia historyczne: albo polityczne, albo gospodarcze. Szczególnie ważną rolę odgrywały także wybitne postaci: Dante Alighieri (1265-1321), Giordano Bruno (1548-1600), Galileo Galilei (1564-1642).

Włoski Renesans przyniósł ze sobą najpierw świeży powiew humanizmu, a po nim rozpoczął się ciąg rewolucji naukowych. Każda z nich na swój sposób utwierdzała zaufanie do funkcjonowania ludzkiego rozumu. W tym samym czasie, ale już w innym kraju, Renè Descartes (1596-1650), posługując się myśleniem stosowanym na gruncie matematyki i geometrii analitycznej, dowodzi niezawodności tegoż rozumu i tworzy podstawy kierunku filozoficznego nazwanego racjonalizmem. Jest to jego silna odmiana, która porządek i skuteczność myślenia czyni gwarantem egzystencji (Cogito ergo sum!). Tędy droga prowadziła dalej, w stronę francuskiego materializmu (Wundt, 1915, s. 22). Jeżeli zaś materia istnieje odwiecznie, to muszą także istnieć odwieczne prawa rządzące jej ruchem. W taki to sposób wiele problemów filozoficznych, chociaż nadal czekających na rozwiązanie, uzyskało nowe sformułowanie. Tym razem naukowe, czyli dostępne badaniom empirycznym. Jak wiadomo, od Kartezjusza przez kilka stacji pośrednich droga wiodła aż do Auguste’a Comte’a (1798-1857). Jego poglądy z pierwszego okresu filozofowania (tzn. przed pobytem w klinice psychiatrycznej) krytycy opatrzyli epitetem „zmatematyzowany materializm”. W okresie późniejszym w jego zainteresowaniach dominowała problematyka społeczna. Wówczas stał się pionierem w zakresie socjologii, a w etyce - twórcą pojęcia altruizmu, które krytycy uznali za zbyt bliskie etyce chrześcijańskiej (Wundt, 1915, s. 28).

Rozwój filozofii angielskiej był zdaniem Wundta w znacznym stopniu niezależny i różny od głównych prądów oraz kierunków rozwoju filozofii na kontynencie europejskim. Odmienności te - coraz to inne - można zauważyć oraz śledzić, poczynając od Dunsa Szkota (1266-1308). Dzieła Francisa Bacona (1561-1626) oraz Jeremy'ego Benthama (1748-1832) wniosły kolejne, nowe akcenty do myśli filozoficznej Wielkiej Brytanii. Pierwszy akcentował znaczenie poznania zmysłowego, drugi zajął się motywami wyznaczającymi przebieg oraz wyniki działania. Istota funkcji motywu miała polegać na wyborze tego, co pożyteczne, i unikaniu tego, co szkodliwe. W ten sposób zostały zarysowane zręby etycznego utylitaryzmu, który stał się orientacją charakterystyczną dla etyki uznawanej zarówno na Wyspach, jak i w Nowym Świecie. Dalszy rozwój tej idei na terenie filozofii angielskiej doprowadził do powstania dwóch odmian utylitaryzmu: jednej, która miała nazwę utylitaryzmu altruistycznego, i drugiej, określonej jako utylitaryzm egoistyczny (Wundt, 1915, s. 67). To właśnie ten ostatni w artykulacji Herberta Spencera (1820-1903) ma być charakterystyczny dla „mentalności angielskiej”, zarówno społecznej, jak i jednostkowej. 
Pierwszym przedstawicielem oryginalnej filozofii niemieckiej byl, zdaniem Wundta, Gottfried Wilhelm Leibniz (1646-1716), którego system filozoficzny charakteryzowało połączenie elementów religijnych i metafizycznych (Wundt, 1915, s. 72 i nn.). Można powiedzieć, że jego filozofia stanowiła próbę przezwyciężenia tych sprzeczności, które po zakończeniu wojny 30-letniej (1618-1648) pozostały nadal nierozwiązane. Również Emanuel Kant (1724-1804) próbował pogodzić w swoim systemie filozoficznym interesy oraz dynamikę powstającego nowego państwa z pietystyczną tradycją rodzinną. Porządek oraz obowiązek stały się tym oryginalnym tworzywem, które znalazło się u podstaw jego systemu, ale także całego świata. Z tego wynikało, że „człowiek” w owym porządku i obowiązkach partycypuje, kiedy jest tego świadom (wiedza) i gdy tego chce (wola) - (Wundt, 1915, s. 102 i nn.). Tego rodzaju orientacja, według Wundta (tamże) jest orientacją idealistyczną. Może jednak przyjmować różne formy - również takie jak u Schopenhauera albo Nietzschego. Wundt nie zgadza się z nimi, ale poznawczo je respektuje.

$\mathrm{Na}$ ostatnich 30 stronach Wundt zajął się analizą funkcjonowania tych naszkicowanych uprzednio systemów filozoficznych oraz orientacji etycznych w warunkach pokoju oraz wojny, a w szczególności w sytuacji trwającej nadal Wielkiej Wojny. Zaraz na wstępie podkreśla to, że wśród wojennych konfliktów i rozgardiaszu niebezpieczeństwo powstania nieporozumień wzrasta. Tradycje myślenia i światopoglądy dominujące $\mathrm{w}$ danym narodzie trzeba brać pod uwagę z respektem i starać się właściwie je zrozumieć. Tędy bowiem wiedzie droga do właściwego zrozumienia i rozwiązania konfliktów. Tradycja może być tym, co utrudnia porozumienie. Ale obok niej równie wielką przeszkodą na drodze do osiągnięcia pokojowego rozwiązania konfliktu może być absurdalne dążenie do panowania nad innymi narodami, wręcz nad światem (Wundt, 1915, s. 135 i nn.). Teraz w końcowej części swojego opracowania zwraca Wundt uwagę na to, że historia poucza, iż to, co nazywamy „narodowym charakterem”, jest jakością i wielkością historycznie zmienną, uwarunkowaną przez czynniki zewnętrzne, wśród których znaczenie szczególne mają sytuacja polityczna danego narodu oraz jego dotychczasowy dorobek kulturowy.

Wundt jest świadom tego, że Cesarstwo Niemieckie rozpoczęło swój udział $\mathrm{w}$ wojnie jako państwo wielonarodowe. $\mathrm{Z}$ ignorancją lub nawet zaprzeczeniem istnienia tej okoliczności! Jednak cała wojna, a w szczególności ofiary ponoszone przez jednostki dla dobra ogółu, spowodowały dalsze postępy w zakresie tworzenia się poczucia narodowej tożsamości (Wundt, 1915, s. 151), w sposób odrębny, ale też specyficzny dla każdej spośród narodowości należących do tych wielonarodowych państwowości, które zajmowały militarne pozycje na różnych odcinkach frontu. Jeżeli wzrost poczucia narodowej tożsamości stanowi efekt udziału w wojnie, to następną płynącą z tego „korzyścią" powinien być wzrost świadomości tego, że reformy polityczne i społeczne stały się koniecznością (Wundt, 1915, s. 153). Problemem będzie teraz pogodzenie sprzecznych interesów 
narodowości, państw oraz poszczególnych grup społecznych. Wundt zdaje sobie sprawę ze złożoności całej sytuacji i kłopotów ze znalezieniem zadowalającego rozwiązania. Wskazuje zatem na rozległą paletę możliwości, którą określają z jednej strony państwowy socjalizm oraz międzynarodowy komunizm (obydwa pod pozorami altruizmu wysycone jednostkowym egoizmem), a z drugiej stare postulaty Fichtego, który już sto lat wcześniej domagał się zapewnienia jednostce możliwości egzystencji i prawa do pracy ${ }^{12}$.

Sens i zabarwienie poglądów Wundta na temat przyszłości Europy po zakończeniu Wielkiej Wojny oddaje dobrze i odważnie odpowiedź na zapytanie Wilhelma Feldmana (1868-1919) ${ }^{13}$. Przypomnę, że w latach 1916-1918 w Charlottenburgu ukazywało się pismo „Polnische Blätter” pod redakcją Wilhelma Feldmana (członka Legionów i emisariusza Józefa Piłsudskiego). Zainteresowany przemówieniem Wundta, Feldman zwrócił się do niego z zapytaniem, jak wyobraża sobie przyszłość Polski po zakończeniu wojny. Oto fragmenty odpowiedzi opublikowanej w czasopiśmie ${ }^{14}$ : „Podobnie jak na początku tej wojny, jestem nadal przekonany, że nigdy więcej nie może być mowy o jakiejkolwiek formie aneksji Polski" (Wundt, 1916, s. 99-100, tł. W.Z.) oraz:

Wszakże już dzisiaj wiemy, że Państwo Polskie jako część niemieckiej Rzeszy już nie będzie nas interesować, natomiast chcielibyśmy mieć to państwo jako pewnego sprzymierzeńca, a jednocześnie jako w najwyższym stopniu wartościową ochronę przed rosyjskim zagrożeniem, które także po zawarciu pokoju nie zmaleje. (Wundt, 1916, s. 100, tł. W.Z.)

Tak pisał poddany Niemieckiego Cesarza, myśląc o przyszłości, której zarys powstawał już w jego umyśle. Ale nie był ów zarys czystym wyobrażeniem, tylko produkcją jego intelektu. Kto był wówczas w stanie tego wielkiego uczonego zrozumieć ${ }^{15}$.

12 Johann Gottlieb Fichte (1762-1814) był jednym z ważniejszych przedstawicieli niemieckiego idealizmu na przełomie wieków XVIII i XIX. Swoje doświadczenia życiowe oraz inspiracje dla własnej filozofii gromadził podczas działalności na obszarze języka niemieckiego: od Zurychu do Królewca. Być może szczególnie ważne były te, które zebrał na terytorium dawnych wojen religijnych. Pod ich wpływem, a także „w cieniu” agresji napoleońskiej, powstało jedno z jego dzieł: Reden an die deutsche Nation (1807/1808), które wywarło szeroki i znaczący wpływ na kształtowanie się poczucia tożsamości narodu niemieckiego w okresie wojen napoleońskich, ale także już po zakończeniu I wojny światowej. Wpływ tego dzieła, głównie ze względu na jego popularność, Wundt respektował zarówno w swoim przemówieniu z roku 1914, jak i w pracy z roku 1915.

13 Był autorem - w okresie międzywojennym - bardzo popularnego opracowania Współczesna literatura polska, które do roku 1930 miało osiem wydań.

14 Ten oraz pozostałe numery czasopisma „Polnische Blätter” są przechowywane i dostępne w Bibliotece Głównej Uniwersytetu im. A. Mickiewicza w Poznaniu.

15 Sens, odwagę autora i polityczną wagę odpowiedzi Wundta dla „Polnische Blätter” zrozumiemy lepiej, jeżeli w tym miejscu przypomnimy fragment o dwa lata późniejszego Pokojowego Programu T.W. Wilsona z 8 stycznia 1918 roku: Punkt 13: Stworzenie niepodleglego 
Czy Wundt wyobrażał sobie, że wojna rosyjsko-polska już po czterech latach, tzn. w roku 1920, stanie się potwierdzeniem jego obaw? Nie będziemy się domyślać. Jego poglądy oraz wystąpienia - zarówno to w Alberthalle, jak w odpowiedzi dla „Polnische Blätter” - wskazują, że rozumiał on znaczenie, ba, nawet potrzebę istnienia narodowej niezależności, opartej na należycie wyartykułowanym poczuciu narodowej tożsamości. Wolność, niepodległość oraz niezależność były warunkami oraz wyrazem jej istnienia. Były swoistą wartością, dobrem, do którego każdy naród miał swoje prawo - własne i niekwestionowalne. Tak myślał Wundt w czasie, gdy istnienie w Europie było możliwe tylko w ramach jednego z cesarstw albo imperiów. Myślę, że trzy omówione tutaj pokrótce dokumenty pokazują zarówno istotę, jak i rozwój poglądów Wundta na temat wojny oraz przyszłości tych narodów, które podczas jej trwania nie miały własnej państwowości. I to spojrzenie w przyszłość narodów, wolne od ram „państwowości” i zależności ukonstytuowanej na średniowiecznych wzorach poddaństwa, stanowi o wartości refleksji Wundta. O jej humanistycznych walorach, ale także o jej uzasadnieniu na podstawie tez wynikających z ustaleń Völkerpsychologie.

\section{CO MYŚLELI O WOJNIE INNI UCZENI?}

$\mathrm{Na}$ temat wojny wypowiedział się także jeden z uczniów Wilhelma Wundta Oswald Külpe (1915). Według niego, w odniesieniu do wojny można wyróżnić trzy odmienne stanowiska etyczne. Pierwsze nazwiemy prowojennym albo utylitarystycznym, przeciwstawne do niego - pacyfistycznym, a trzecie - realistycznym. Wojnę, ujętą w kategoriach etycznych, można uznać za usprawiedliwioną, gdy została podjęta $\mathrm{w}$ celu obrony wolności lub egzystencji danego narodu (więcej: Zeidler, 2008, s. 237-238). Uwagi Külpego były ograniczone do kręgu etyki. Inne podejście do tej problematyki zaprezentował Peter Hoeres (2004). Odwołując się do archiwalnych dokumentów, rekonstruował on treść oraz sposób prowadzenia „wojennych dyskusji” lub polemik przez uczonych i publicystów należących do dwóch walczących ze sobą obozów (Niemcy i Wielka Brytania). Okazało się, że po każdej z walczących stron można było znaleźć reprezentantów każdego z trzech stanowisk etycznych wyróżnionych przez Oswalda Külpego.

Jeszcze inni powiadają o przemówieniu Wundta w Alberthalle 10 września 1914 roku, że zostało ono wygłoszone w stanie patriotycznego uniesienia przez uczonego znanego z osiągnięć w zakresie... psychologii eksperymentalnej. Jest to wyraźne uproszczenie. Ignoruje ono bowiem charakterystyki, które dotyczą

państwa polskiego na terytoriach zamieszkanych przez ludność bezsprzecznie polska, z wolnym dostępem do morza, niepodległością polityczna, gospodarczą; integralność terytorialna tego państwa ma być zagwarantowana przez konwencję międzynarodowa (Czternaście punktów Wilsona. (b.d.). Pobrane z: https://pl.wikipedia.org/wiki/Czternascie_punktow_Wilsona). 
zarówno samego wystąpienia, jak i osoby badacza. Trzy spośród nich są szczególnie ważne. Pierwsza dotyczy specyfiki poglądów etycznych Wundta, druga - jego kompetencji w zakresie historii, a trzecia specyfiki jego poglądów naukowych. Peter Petersen $(1925, \text { s. } 257)^{16}$ uważał, że specyfikę etycznych poglądów Wundta stanowi konsekwentne przeciwstawianie utylitaryzmu idealizmowi. To właśnie ta opozycja, jako swoisty rodzaj idealizacji, stanowiła konstrukcję wystąpienia Wundta w dniu 10 września 1914 roku. Dowody na rzecz jego kompetencji w zakresie historii znajdziemy w pracach o charakterze wyraźnie historycznym.

Tymczasem la Grand Guerre, jak każda wojna, była dziełem ponurym, rozpętanym przez kolejne fale sprzeczności rywalizujących ze sobą imperializmów oraz prób zniewolenia całych narodów w imię interesów cesarskiego państwa lub - coraz to innego - imperium. Wundt nie zastanawiał się nad tym, czy podstawę owej rywalizacji stanowiła frustracja czy asertywność. On oglądał problem $\mathrm{w}$ perspektywie przyjętych za punkt wyjścia idealizacji. W jego wystąpieniu w Alberthalle szczególnie dobitny wyraz znalazły dwie: wolność i samodzielność. Każda z nich miała zastosowanie zarówno na płaszczyźnie jednostkowej, jak i narodowej. Niepodległość jest bowiem warunkiem rozwoju tak samo jednostki, jak narodu ${ }^{17}$. Wolność w rozumieniu Wundta jest podstawowym prawem każdego z narodów, a jej warunkiem i wyrazem jest samodzielność. Prawo do wolności ma najpierw naród, a dopiero wtórnie państwo.

Wspomniany już Leonhard (2014, s. 461) powiada, że w tej wojnie nagrodą za ofiary poniesione w bitwach na froncie wschodnim było odzyskanie wolności, narodowej samodzielności i uzyskanie państwowości. Wolność mogła się cieszyć sama sobą, bez pomników, które przypominałyby czas zniewolenia.

\section{ZŁożoność Poglądów Wilhelma Wundta}

W chwili wybuchu I wojny światowej Wilhelm Wundt miał 81 lat, ale nadal kierował Instytutem Psychologii Uniwersytetu w Lipsku ${ }^{18}$. Jego zasługi dla

16 Peter Petersen (1884-1952) podczas „studiów” w Poznaniu przygotował rozprawę doktorską Idea rozwoju w filozofii Wundta, którą obronił w roku 1908 w Jenie. Książka, opublikowana w roku 1925, przyniosła mu uznanie jako znawcy poglądów filozoficznych Wundta. Jego system pedagogiczny (respektowanie indywidualności ucznia) jest nadal stosowany programowo w niektórych szkołach w Niemczech.

17 Wspomniany już Leonhard (2014, s. 320 i n.) podkreśla, że owa Grand Guerre oprócz innych cech miała także charakter „narodotwórczy”, co znaczy, że budziła oraz umacniała poczucie narodowej tożsamości. Właściwe w tym kontekście określenie „naród” stanowiło przeciwieństwo określenia „państwo”. Określenie Volk niesie treść bogatą i niejednorodną. Bywa też tak, że należy je rozumieć „intuicyjnie”, tak jak to miało miejsce podczas demonstracji w NRD w roku 1989: Wir sind ein Volk!

18 Oficjalnie, decyzją Królewskiego Ministerstwa Saksonii, instytut ten został powołany do życia w roku 1883 (por. Wundt, 1910), to znaczy, że Wundt - od tego momentu poczynając był jego dyrektorem przez 30 lat (!). 
rozwoju psychologii naukowej są znane. Przypomnę, że dopiero w roku 1913 (Wundt, 1920, s. 307-310) przy Instytucie Psychologii w Lipsku powstał Zakład Völkerpsychologie. W tym terenie - już od dłuższego czasu koncentrowały się badania Wilhelma Wundta. Jego samego, a także jego uczniów, o nazwiskach tak znanych jak Aleksander Świętochowski (1849-1938) lub Hugo Münsterberg (1863-1916). Wundt nie budował swoich poglądów, wychodząc od obserwacji mentalności mieszkańców wielkich miast (Simmel, 2005). Jego koncepcja Völkerpsychologie nawiązywała do treści, które miały początek w antropologii kulturowej Wilhelma von Humboldta (1797/1999) i w koncepcji Moritza Lazarusa $^{19}$ (por. Sganzini, 1913). Koncepcja Lazarusa opierała się na psychologii Herbarta $^{20}$, z którym Wundt się nie zgadzał, dlatego był zmuszony budować swoją Völkerpsychologie od podstaw. Poglądy Wundta znalazły uznanie ówczesnego środowiska naukowego poza granicami zarówno Saksonii, jak i Niemiec. Carlo Sganzini (1913) ${ }^{21}$ przedstawił szczegółowe, krytyczne analizy koncepcji Völkerpsychologie Moritza Lazarusa oraz Wilhelma Wundta. O ile Lazarus pozostaje w zgodzie z teoriopoznawczymi wątkami psychologii Herbarta, o tyle Wundt jak twierdzi Sganzini (1913, s. 97) - buduje swoją wersję Völkerpsychologie na wątkach przejętych $\mathrm{z}$ etyki. Jednakże niekoniecznie tej moralizatorskiej, ale zabiegającej o to, aby kontakty międzyludzkie były dobrze zorganizowane, spolegliwe i oparte na wzajemnej życzliwości. Podobne do tych, jak je sobie wyobrażał i opisał Ignacy P. Legatowicz (1859, w broszurze pt. Dawna przodków naszych obyczajność).

Aby lepiej uświadomić sobie rozległość i złożoność poglądów naukowych Wundta, należy przypomnieć, że w pierwszym etapie swojego życia zdobył on wykształcenie medyczne i był także deputowanym do Parlamentu Badenii. Zamknięciem tego okresu była praca $\mathrm{z}$ roku 1863: Vorlesungen über die Menschen- und Thierseele. Zauważyć należy - co wielu historyków psychologii ignoruje - że już we wstępie do tej pracy stwierdził, iż psychologia eksperymentalna oraz Völkerpsychologie stanowią dwa odrębne, ale podstawowe działy (Fundamentalgebiete) naukowej psychologii (Wundt, 1863/1879, s. 12). A był to dopiero rok 1863! W roku 1874 - mając lat 42 - został profesorem filozofii,

19 Moritz Lazarus (1824-1903) - ur. w Filene (obecnie Wieleń n. Notecią). Otrzymał w roku 1859, pierwszą w obszarze języka niemieckiego, Katedrę Psychologii w Uniwersytecie w Bernie (Szwajcaria), później pracował w Berlinie. Jest uważany za pierwszego twórcę Völkerpsychologie.

20 Johan Friedrich Herbart (1776-1841) - w latach 1809-1833, jako następca Kanta, kierował Katedrą Filozofii w Uniwersytecie w Królewcu. Dzięki bliskim kontaktom z Wilhelmem von Humboldtem wywarł znaczący wpływ na kształt pedagogiki w Niemczech. Zwolennikiem jego poglądów w Lipsku za czasów Wundta był profesor matematyki i filozofii tamtejszego Uniwersytetu - Moritz Drobisch (1802-1896).

21 Carlo Sganzini (1881-1946) - od roku 1923 był profesorem psychologii Uniwersytetu w Bernie i kierował tam Katedrą Psychologii, utworzoną w roku 1859 dla Moritza Lazarusa. 
przedtem jednak skierował swoje zainteresowania od fizjologii ku psychologii. Wtedy powstał program jego naukowych poszukiwań na kolejne etapy jego życia i twórczości, aby uzyskać spełnienie w roku 1913, w postaci utworzenia przy Uniwersytecie w Lipsku Zakładu Völkerpsychologie.

Integracja całości poglądów Wundta z ówczesną psychologią tradycyjną była kłopotliwa. Dobitnie wyraził to Adam Stögbauer (1881-1916):

Jak wiemy, istnieje jednak granica, od której począwszy heurystyczna zasada psychofizycznego paralelizmu okazuje się niewystarczająca: stanowią ją twory psychiczne wyższego rzędu, kompleksy, które w miarę swojej złożoności oddalają się coraz bardziej od swoich fizycznych korelatów, a tem samem stają się coraz mniej dostępne dla eksperymentu. $(1914$, s. 32$)$

Stworzenie syntezy tych dwóch działów psychologii było zadaniem, którego świadomość towarzyszyła Wundtowi przez ponad 50 lat jego życia. Dostrzegał jednak to, że związki oraz odmienności psychologii eksperymentalnej oraz Völkerpsychologie rozpoczynają się na poziomie metodologicznym albo wręcz epistemologicznym (por. 1908, s. 225 i nn.).

Centralnymi pojęciami w koncepcji Völkerpsychologie były: język, mity i obyczaje, które zdobyły funkcję swoistego tworzywa także w innych działach naukowej psychologii (por. Wundt, 1907, s. 365-385). Przy tym każde z nich jako punkt odniesienia miało pierwotną, idealną strukturę społeczną, zbudowaną z kontaktów bezpośrednich, czyli wcześniejszą niż te, które generowała mentalność mieszkańców wielkich miast (Simmel, 2005). Wundt był także zwolennikiem koncepcji rozwoju traktującej rozwój ontogenetyczny i filogenetyczny (por. np. 1908) jako powiązane wzajemnie i zwrotnie (więcej na ten temat: Danzel-Hamburg, 1921).

Na szczególną uwagę zasługuje rozumienie przez Wundta zasady przyczynowości. Jego zdaniem zasada ta $\mathrm{w}$ rozumieniu stosowanym $\mathrm{w}$ naukach przyrodniczych, zarówno w odniesieniu do historii narodów, jak i jednostek nie ma zastosowania. Jest bowiem tak, że poszczególne wydarzenia w historii narodów, jak i działania jednostek ludzkich nie zależą od przyczyn koniecznych i jednoznacznych, ale od dowolnych d e c y z ji konkretnych jednostek lub grup społecznych. Na tym terenie czynnikiem elementarnym i konstytutywnym są decyzje. Każdą z nich cechuje dowolność i posiadanie motywu. Wybory jednostki są wprawdzie kontrolowane (etyka), ale dokonują się one na podstawie zasady wolności (Wundt, 1863/1897, s. 489 i nn.). Swoboda wyboru ma dwa aspekty. Jako niezależna od przyrodniczej zasady przyczynowości, ma pewien aspekt ontologiczny. Jednak jako podporządkowana zasadom współżycia obowiązującym w danej grupie, ma też aspekt etyczny. Już w tej konstrukcji umysłowej można rozpoznać podstawę tego, co nazywamy wolnością. Jest to jednak wolność szczególna! Implikuje konieczność podejmowania decyzji, a jednocześnie jest instancją, która chroni niezależność owych decyzji od wszelkich 
nacisków zewnętrznych, szczególnie tych, które swobodę wyboru znoszą lub ograniczają. Wolność, w zakresie wyboru motywów działania i podejmowania decyzji, stanowi niezbędny warunek rozwoju zarówno w aspekcie filo-, jak i ontogenetycznym. W tym kontekście wszelkie formy przymusu i gwałtu stanowią przeciwieństwo wolności, niejako ex definitione! Z tej samej racji, w koncepcji Wundta, naród zachowuje swoistą autonomię w stosunku do państwa.

Zarówno jednostki ludzkie, jak i podstawowe grupy (albo wspólnoty) ludzkie mają szczególną właściwość i organizację, nazywaną wolą. To właśnie ona zastępuje przyrodniczą zasadę przyczynowości. Jej działanie charakteryzuje to, że zamiast odwoływać się do przyczyn tkwiących w przeszłości, orientuje się ku przyszłości i na zasadzie swoistej projekcji umieszcza przed sobą cele, do których dąży. Funkcjonowanie tej projekcji (por. Wundt, 1907, s. 219-245) $\mathrm{w}$ konwencji idealizującej - implikuje zarówno istnienie, jak i funkcjonowanie zasady racjonalności działającego podmiotu. Zatem wszędzie tam, gdzie miejsce racjonalności zajmuje przemoc, gdzie występują eksplozje emocji lub ich tłumienie, mamy do czynienia $\mathrm{z}$ naruszeniem reguł lub praw funkcjonowania człowieka jako racjonalnego podmiotu.

Ten, kto zechce, rozpozna tutaj przypisywaną Wundtowi w starych podręcznikach psychologii zasadę woluntaryzmu. Była to konstrukcja poznawcza, która oddawała poglądy Wundta w sposób uproszczony. Wundt odróżniał zjawiska fizjologiczne od psychicznych. Widział też konieczność wyłączenia zjawisk psychicznych z zakresu działania zasady przyczynowości pojmowanej przyrodniczo (Wundt, 1863/1897, s. $489 \mathrm{i}$ nn.). Wprowadził zatem nową strukturę psychiczną, którą nazwał „motywem”. Motyw w jego ujęciu (Wundt, op. cit., Wundt, 1863/1897, s. 489 i nn., 1907, s. 219-245) spełniał trzy funkcje. Owszem, energetyzował działanie, ale także dokonywał wyboru i projekcji celu w kierunku przyszłości, a następnie ustalał sposoby osiągnięcia tego celu. Wundt był jednak przede wszystkim racjonalistą i dlatego troszczył się o to, aby, w jego koncepcji, człowiek był istotą rozumną. Oczywiście agresja, także ta wojenna, będzie w jego oczach „działaniem”, które należy „sprawdzić” pod względem jego racjonalności. Albowiem działania społeczne, polityczne czy ideologiczne mogą naruszać zasadę racjonalności lub być z nią sprzeczne! Mogą także naruszać wolność osobistą jednostek ludzkich lub całych narodów!

W ciągu wielu lat swojej wielotorowej działalności oraz rozległych studiów naukowych Wundt skonstruował aparat naukowy, który pozwalał mu rozpatrywać w obrębie jednego systemu (por. Petersen, 1925), w realiach ówczesnej rzeczywistości politycznej, zjawiska i wydarzenia lokowane w szerokim spectrum, rozciągającym się od fizjologii aż do kultury. I to właśnie ta okoliczność powodowała, że uznawane przez niego wartości były sprzeczne z pojmowaniem wartości w ramach nadciągającego utylitaryzmu oraz pragmatyzmu. Nietrudno zauważyć, że cały system jego poglądów nie był posłuszny ówczesnej rzeczywistości politycznej, ale wartościom humanistycznym. Owszem, jego poglądy 
wybiegały w przyszłość, w kierunku rzeczywistości, ale tej, którą należało zbudować, zdaniem Wundta, według zasad idealizmu, a nie egoizmu i pragmatyzmu. Czy w tym dziele było jednak miejsce dla psychologii? Dla psychologii tamtego czasu?

\section{ZAKOŃCZENIE}

Swoje przemówienie z 10 września 1914 roku, wygłoszone sześć tygodni od momentu rozpoczęcia wojny, Wundt zakończył wezwaniem pokojowym. Przypuszczać należy, że pokojowe współżycie między narodami na tle ówczesnej mentalności było dla większości społeczeństw nie tylko trudne do akceptacji, lecz także - i przede wszystkim - trudne do zrozumienia i wyobrażenia. Czy Wundt miał świadomość tego, że Wielka Wojna kończyła okres panowania monarchii w Europie i torowała drogę w kierunku demokracji? Czy pominięcie państwa na kontinuum naród-Europa trzeba uznać za błąd autora Volkerpsychologie? Czy był ktoś inny, kto już wówczas doceniał znaczenie i postulował zjednoczenie Europy? Czy wreszcie istnienie Europy było do pogodzenia $\mathrm{z}$ istnieniem imperiów?

Swoje optymistyczne poglądy na temat pokojowej koegzystencji krajów Europy Wundt oparł na istnieniu pewnego kontinuum, biegnącego od humanizmu przez ciąg rewolucji naukowych aż hen, w kierunku nieznanej jeszcze przyszłości, ale właśnie tej, jaką ludzie wolni stworzą sami dla siebie. $Z$ tej racji było rzeczą ważną korzystanie $\mathrm{z}$ różnych tradycji myślenia i respektowanie odmiennych światopoglądów.

W swojej odpowiedzi na pytanie zadane na łamach „Polnische Blätter” Wundt pojawił się jako uczony wielkiego formatu i niezwykle odważny. Przyznawał, że Cesarstwo Niemieckie uczestniczy w wojnie jako państwo wielonarodowe. Zaraz potem prognozowal jego rozpad. W ówczesnej atmosferze taka prognoza świadczyła jednoznacznie o dociekliwości, ale także o obiektywizmie i odwadze Autora.

\section{Bibliogr AFIA}

Ash, M.G. (1980). Wilhelm Wundt and Oswald Külpe on the Institutional Status of Psychology: An Academic Controversy in Historical Context. W: W.G. Bringmann, R.D. Tweney (red.), Wundt Studies (s. 396-421). Toronto: C.J. Hogrefe.

Clark, C. (2012). The Sleepwalkers. How Europe Went to War in 1914. Londyn: Allen Lane/Penguin.

Clark, C. (2013, styczeń 2014, wyd. 10). Die Schlafwandler: Wie Europa in den Ersten Weltkrieg zog. Monachium: Deutsche Verlags-Anstalt. 
Danzel-Hamburg, Th.W. (1921). Prinzipien und Methoden der Entwicklungspsychologie. Berlin/Wiedeń: Urban \& Schwarzenberg.

Eilers, K. (1928). Wundt Max, Was heißt völkisch? Kant-Studien, 33(1/2), 305-306. Einstein, A., Freud, S. (1972). An Sigmund Freud. W: Warum Krieg? (s. 13-22). Zurych: Diogenes Verlag.

Fischer, F. (1961). Griffnach der Weltmacht. Die Kriegszielpolitik des kaiserlichen Deutschland 1914/1918. Düsseldorf: Droste.

Geuter, U. (1985). Polemos panton pater - Militär und Psychologie im Deutschen Reich 1914-1945. W: M.G. Ash, U. Geuter (red.), Geschichte der deutschen Psychologie im 20. Jahrhundert (s. 146-171). Opladen: Westdeutscher Verlag. Hoeres, P. (2004). Krieg der Philosophen. Paderborn, Monachium, Wiedeń, Zurych: Verlag Ferdinand Schöningh.

Humboldt von, W. (1797/1999). Plan einer vergleichender Anthropologie. W: W. Stahl (red.), Wilhelm von Humboldt. Sämtliche Werke, Schriften zur Sprachphilosophie I. (1820-1829) (s. 11-23).

Köhler, W. (1928). Carl Stumpf zum 21. April 1928. Kant-Studien, 33(1-2), 1-3. Külpe, O. (1915). Die Ethik und der Krieg. Lipsk: Verlag S. Hirzel.

Lamberti, G. (1995). Wilhelm Maximilian Wundt (1832-1920). Leben, Werk und Persönlichkeit in Bildern und Texten. Bonn: Deutscher Psychologen Verlag. Legowicz, I.P. (1859). Dawna przodków naszych obyczajność. Wilno: Drukarnia Józefa Zawadzkiego.

Leonhard, J. (2014). Die Büchse der Pandora. Geschichte des Ersten Weltkrieges. Monachium: Verlag C.H. Beck.

Lück, H.E. (1997). Münsterberg, Hugo. W: Neue Deutsche Biographie, 18 (s. 542-543). Berlin: Duncker \& Humblot. http://www.deutsche-biographie. de/ppn118785281.html

Meischner, W., Eschler, E. (1979). Wilhelm Wundt. Lipsk-Jena-Berlin: Urania-Verlag.

Münsterberg, H. (1912). Die Amerikaner. Zweiter Band: Das geistige und soziale Leben. Berlin: E.S. Mittler, Königliche Hofbuchhandlung.

Münsterberg, H. (1915). Amerika und der Weltkrieg - ein amerikanisches Kriegstagebuch. Lipsk: Johan Ambrosius Barth.

Münsterberg, H. (1916, wyd. III). Psychologie und Wirtschaftsleben. Ein Beitrag zur angewandten Experimental-Psychologie. Lipsk: Verlag Johann Ambrosius Barth.

Petersen, P. (1925). Wilhelm Wundt und seine Zeit. Stuttgart: Fr. Frommanns Verlag.

Rolland, R., Zweig, S. (2014). Von Welt zu Welt. Briefe einer Freundschaft. Berlin: Aufbau.

Scheerer, E. (1989). Kämpfer des Wortes: Die Ideologie deutschen Psychologen im Ersten Weltkrieg und ihr Einfluß auf die Psychologie der Weimarer Zeit. Psychologie und Geschichte, 1(3), 12-22. 
Schönpflug, W. (2000). Geschichte und Systematik der Psychologie. Weinheim: Beltz, PsychologieVerlagsUnion.

Schubeius, M. (1990). Und das psychologische Laboratorium muss der Ausgangspunkt pädagogischer Arbeiten werden. Frankfurt n./M.: Peter Lang. Sganzini, C. (1913). Die Fortschritte der Völkerpsychologie von Lazarus bis Wundt. Berno: Verlag von A. Francke.

Simmel, G. (2005). Mentalność mieszkańców wielkich miast. W: G. Simmel, Socjologia (s. 305-315). Warszawa: PWN.

Simmel, G. (2007). Filozofia kultury. Kraków: Wydawnictwo Uniwersytetu Jagiellońskiego.

Staeuble, I. (1985). „Subjektpsychologie“ oder „subjektlose Psychologie“ Gesellschaftliche und institutionelle Bedingungen der Herausbildung der modernen Psychologie. W: M.G. Ash, U. Geuter (red.), Geschichte der deutschen Psychologie im 20. Jahrhundert (s. 19-44). Opladen: Westdeutscher Verlag.

Steinberg, H. (red.). (2002). Der Briefwechsel zwischen Wilhelm Wundt und Emil Kraepelin. Berno: Hans Huber.

Stögbauer, A. (1914). Psychologia Wundta i jej geneza. Lwów: Nakł. P. T. Pedagogicznego.

Wundt, W. (1863/1897). Vorlesungen über die Menschen- und Thierseele. Hamburg, Lipsk: Verlag von Leopold Voss.

Wundt, W. (1907). Grundriss der Psychologie. Lipsk: Verlag von Wilhelm Engelmann (wyd. VIII).

Wundt, W. (1908). Logik der Geisteswissenschaften. Stuttgart: Verlag von Ferdinand Enke.

Wundt, W. (1910). Das Institut für experimentelle Psychologie. Psychologische Studien, 5, 279-293.

Wundt, W. (1914). Über den wahrhaften Krieg. Rede gehalten in der Alberthalle zu Leipzig am 10. September 1914. Lipsk: Kröner.

Wundt, W. (1915). Die Nationen und ihre Philosophie. Ein Kapitel zum Weltkrieg. Lipsk: Alfred Kröner Verlag.

Wundt, W. (1916). Zur Lage. Polnische Blätter, 5, 99-101.

Wundt, W. (1920). Erlebtes und Erkanntes. Stuttgart: A. Kröner Verlag.

Zeidler, W. (2008). Początki polsko-niemieckich kontaktów w zakresie psychologii. W: H.E. Lück, Historia psychologii - orientacje, szkoły i kierunki rozwoju (s. 225-245). Warszawa: VIZJA PRESS\&IT.

Zeidler, W. (2011). Kwestionariusze w psychologii: kierunki rozwoju i pierwsze filiacje teoretyczne. W: W. Zeidler (red.), Kwestionariusze w psychologii. Postępy, zastosowania, problemy (s. 15-78). Warszawa: VIZJA PRESS \& IT. 